\title{
Horizontal Cane Orientation and Rowcover Application Improve Winter Survival and Yield of Trailing 'Siskiyou' Blackberry
}

\author{
Fumiomi Takeda ${ }^{1,3,5}$ and John Phillips ${ }^{2,4}$
}

ADDITIONAL INDEX WORDs. $R u b u s$, trellis, primocane, floricane, fruit, protected cultivation, temperature, bud

SUMMARY. Using the rotating cross-arm (RCA) trellis and cane training system, lateral canes of trailing 'Siskiyou' blackberry (genus $R u b u s$ subgenus $R u b u s$ ) were kept vertically or rotated down to horizontal so that plant canopy was close to the ground. In winter, the plots were either covered with a non-woven rowcover (RC) or left uncovered. Cane injury was least in plants with lateral canes oriented horizontally and covered. Cane injury was high in plants with lateral canes oriented vertically in winter, whether covered or not, and among plants with lateral canes laid close to the ground but not covered. Among 'Siskiyou' plants that had lateral canes oriented horizontally, 280 flower clusters and $6.0 \mathrm{~kg}$ fruit/plant were produced on plants that had a RC in the winter compared with only 72 flower clusters and $1.7 \mathrm{~kg}$ fruit/plant for plants that were not covered in winter, in 2009. Fewer flower clusters developed and the yield was $\leq 2 \mathrm{~kg} /$ plant on plants with lateral canes oriented vertically. Yield differences between the most and least productive treatments were low in 2010 because of milder winter conditions and snowfall during the coldest periods that fully or partially covered the lateral canes oriented horizontally and close to the ground. The RC treatment had no effect on cane injury or yield when lateral canes were oriented vertically. The findings suggested that 'Siskiyou' blackberry can be grown in the eastern United States, where winter injury has frequently caused a crop failure, by positioning the lateral canes close to the ground and covering plants with a RC.

$\mathrm{F}$ resh market blackberry production has increased in the United States in the last 10 years. Commercial acreage of erect and trailing blackberry has expanded most notably in California (M. Jimenez, personal communication) and of erect blackberry in Georgia (G. Krewer, personal communication) and North Carolina (G. Fernandez, personal communication). However, western trailing blackberry is rarely planted in mid-Atlantic coast region because temperatures $<-12{ }^{\circ} \mathrm{C}$ are common during the winter [U.S. Department of Agriculture (USDA), 2004]. Current commercial trailing blackberry, grown mainly in

\footnotetext{
An appreciation is extended to Franklin Adams, Sharon Jones, Lisa Hopkins, and Ann K. Rose for detailed data collection and plot maintenance work. Special thanks go to Elizabeth Ogden for performing freezing studies.

${ }^{1}$ Appalachian Fruit Research Station, Agricultural Research Service, U.S. Department of Agriculture, 2217 Wiltshire Road, Kearneysville, WV 25430

${ }^{2}$ North Atlantic Area, Agricultural Research Service, U.S. Department of Agriculture, 600 East Mermaid Lane, Wyndmoor, PA 19038

${ }^{3}$ Research Horticulturist

${ }^{4}$ Statistician

${ }^{5}$ Corresponding author. E-mail: fumi.takeda@ars.usda.
} gov.
USDA Plant Hardiness Zones 8 and 9 (Cathey, 1990), such as Willamette Valley, OR, and San Joaquin Valley, $\mathrm{CA}$, suffers winter injury when temperatures drop below $-10{ }^{\circ} \mathrm{C}$ (Crandall, 1995), and this has limited the expansion of trailing blackberry outside Oregon, Washington, and California where winter conditions are mild. In controlled freezing studies, Cortell and Strik (1997) reported that canes and buds of western trailing 'Marion' blackberry survived temperatures as low as $-22^{\circ} \mathrm{C}$ in one year, but only to $-10{ }^{\circ} \mathrm{C}$ in another year. In Oregon, 'Siskiyou', a western trailing blackberry, did not show visible injury after a winter when temperatures dropped to $-12{ }^{\circ} \mathrm{C}$ on several nights (Finn et al., 1999). In the upper Piedmont region of North Carolina (USDA Plant
Hardiness Zone 7b), where fluctuating sub- $0{ }^{\circ} \mathrm{C}$ temperatures in winter are common, 'Siskiyou' blackberry did not produce a crop (J. Ballington, personal communication). However, in the eastern United States, the interest in growing trailing blackberries still exists among small and part-time farmers looking for a niche market and an early-season crop.

For blackberry production to expand into areas with more severe winter conditions, cultivars with increased winterhardiness and systems to protect blackberry plants from winter injury are needed. Improved trellis design and cane-training techniques along with enhanced winter protection strategies and improved harvest efficiency have enabled diversification for small farms and opened up niche markets (Takeda et al., 2008). A wide variety of techniques, such as RCs, coldframes, plasticulture, plastic-covered and glass greenhouses, and high tunnels, have been used to modify the environment for vegetable (Lamont, 2005; Wells and Loy, 1985) and berry crops (Demchak, 2009; Pritts et al., 1999) and for extending the production season. Besides modifying soil and air temperatures, these techniques also protect plants from wind damage and may limit pests.

At the Appalachian Fruit Research Station (AFRS) in Kearneysville, WV, a novel trellis system called the rotating cross-arm trellis and unique cane-training technique aided mechanical harvesting of fresh market quality fruit of eastern thornless blackberries (Harper et al., 1999; Takeda and Peterson, 1999). The RCA trellis design is similar to the shift trellis system described by Stiles (1999). The RCA system has a short upright post (24 inches) with a 5 -ft-long cross-arm at the top of the post that rotates as much as $180^{\circ}$ (Takeda and Peterson, 1999) and is now commercially marketed by Trellis Growing Systems [TGS (Fort Wayne, IN)]. The drawings of RCA trellis are

\begin{tabular}{llll}
\hline $\begin{array}{l}\text { Units } \\
\begin{array}{l}\text { To convert U.S. to SI, } \\
\text { multiply by }\end{array}\end{array}$ & U.S. unit & SI unit & $\begin{array}{l}\text { To convert SI to U.S., } \\
\text { multiply by }\end{array}$ \\
\hline 0.3048 & $\mathrm{ft}$ & $\mathrm{m}$ & 3.2808 \\
2.54 & inch $(\mathrm{es})$ & $\mathrm{cm}$ & 0.3937 \\
0.4536 & $\mathrm{lb}$ & $\mathrm{kg}$ & 2.2046 \\
33.9057 & $\mathrm{oz} / \mathrm{yard}^{2}$ & $\mathrm{~g} \cdot \mathrm{m}^{-2}$ & 0.0295 \\
$\left({ }^{\circ} \mathrm{F}-32\right) \div 1.8$ & ${ }^{\circ} \mathrm{F}$ & ${ }^{\circ} \mathrm{C}$ & $\left(1.8 \times{ }^{\circ} \mathrm{C}\right)+32$
\end{tabular}


available at their website (TGS, 2010). The details of cane training technique developed for this trellis system are provided elsewhere (Takeda et al., 2003, 2008). In the fall, the lateral canes that were tied to the wires on RCA trellis during the growing season are inclined to a horizontal position. Inclination of the lateral canes close to the ground ( $\approx 20$ inches) creates a plant shape conducive for the placement of winter protection material over the plant. In spring, the RC is removed and after flowering shoots emerge from buds on the lateral canes and grow upward, the cross-arm is rotated through the vertical and to an additional $30^{\circ}$ so that much of the fruit hangs on one side of a narrow canopy below the cross-arm without causing cane breakage. 'Siskiyou' plants that were low to the ground and covered with one layer of RC produced $\approx 5 \mathrm{~kg}$ of fruit per plant while plants in the open produced $<2 \mathrm{~kg}$ fruit/plant during all previous 6 years (20032008 ) (Takeda et al., 2008). On the basis of these findings, we hypothesized that the combination of having canes close to the ground and covering them with $\mathrm{RC}$ would be more effective in reducing winter injury than covering the upright canes. The objective of this study was to determine the effect of lateral cane orientation and winter RC application on bud survival, cane injury, and productivity of 'Siskiyou' trailing blackberries.

\section{Materials and methods}

Nursery mature 'Siskiyou' transplants were established on raised beds, covered with black landscape fabric at AFRS (lat. $39.5^{\circ} \mathrm{N}$, long. $77.9 \mathrm{~W}, 590$ $\mathrm{ft}$ elevation, USDA Plant Hardiness Zone 6b) in Spring 2001. Rows were spaced $11 \mathrm{ft}$ apart and oriented in the north-south direction with an interrow spacing of $5 \mathrm{ft}$ between plants. Plot maintenance and pest control followed the established bramble production guidelines for the region (Demchak, 2006). A RCA trellis was installed in Fall 2001. During May and June 2008 and 2009, three primocanes per plant were bent and tied to the training wire 20 inches off the ground when each were $\approx 24$ inches tall. All primocanes selected for training were bent to grow to the north and were tipped when they reached the adjacent plant $5 \mathrm{ft}$ away. Lateremerging primocanes were removed before they were 20 inches tall. Lateral canes that emerged from axillary buds on the tied canes were restricted to the angle created by the wires on the main arms inclined $20^{\circ}$ in the harvest position and movable short arms on the other side of the post. Lateral canes were tied to wires on the main cross-arms at 2-week intervals from June to September. All canes grown beyond the topmost wire on the main cross-arm were tipped in November. Floricanes were pruned in August after the harvest was complete. In late November, the crossarm was either kept vertical $(\mathrm{V})$ or rotated away from the harvest position and downward so that the crossarms were below horizontal $(\mathrm{H})$ (e.g., tip touched the ground).

A $1.5 \mathrm{oz} / \mathrm{yard}^{2}$ RC (GS-51; Atmore Industries, Atmore, AL) was applied to plants with the lateral canes oriented vertically and to plants with the lateral canes oriented horizontally in early Dec. 2008. Five plants with vertically oriented lateral canes and 10 plants with horizontally oriented lateral canes were left uncovered. In early Mar. 2009, the RC was removed. On plants with lateral canes that were vertically oriented in winter, the crossarms were rotated down to maintain the canes inclined horizontally in early March and allow it to remain in that position until the flowering laterals emerged from the axillary buds on the lateral canes. Once bloom occurred, the cross-arms in all sections were rotated up to vertical and an additional $20^{\circ}$ to harvest position.

In May 2009, the lateral canes were counted and each primocane and each lateral cane was assessed for viability. The periderm near the distal end of the 5 - $\mathrm{ft}$ lateral canes was scrapped to reveal green underlying tissues (presumably viable phloem). Flowering shoots on each lateral cane were counted, and mature fruit were harvested twice weekly from 18 June to 2 July 2009 and from 14 June to 7 July 2010.

Two temperature sensors (WatchDog ${ }^{\circledR}$ Model 125; Spectrum Technologies, Plainfield, IL) recorded air temperatures in each of the seven 5plant sections at 30 -min intervals from mid Dec. 2008 to Feb. 2009 and from 1 Dec. 2009 to 28 Feb. 2010. All sensors used to record air temperature were encased in radiation shields. In the treatment plots with lateral canes oriented horizontally, the sensors were located 12 inches aboveground, and in vertically oriented plots, the sensors were located $5 \mathrm{ft}$ aboveground. Hourly temperature averages were used to generate boxand-whisker plots (SigmaPlot 10; SYSTAT Software, Chicago, IL).

In 2008-2009, the study consisted of 18 'Siskiyou' plants with lateral canes oriented horizontally, of which half were covered in early December with the RC used in the 2008-2009 study. There were 15 plants with lateral canes oriented vertically, of which 10 were also covered with RC. For the remaining five plants, the lateral canes were maintained upright throughout winter and without RC. Data were analyzed using each plant as a replicate with General Linear Model analysis of variance (ANOVA). When differences were detected at $P \leq 0.05$, the data were subjected to mean separation by differences of least square means using SAS Proc Mixed and using the arcsine transformation (SAS version 9.1, SAS Institute, Cary, NC).

In 2009-2010, the experiment was performed in a single, $200-\mathrm{ft}$ long row of 'Siskiyou' plants trained to the RCA trellis (Fig. 1). The study consisted of three and four replicates of two main treatment (e.g., $\mathrm{V}$ or $\mathrm{H}$ cane orientation) blocks. In each of the main treatment plots, one-half of the plants (e.g., two or three plants spaced $5 \mathrm{ft}$ apart) were covered with a $\mathrm{RC}$ and the remaining plants were left uncovered. There were a total of 14 plots, and each five consecutive plants in a row of 'Siskiyou' plants represented either of the two main-plot treatments (e.g., $\mathrm{V}$ and $\mathrm{H}$ ), and two subplot treatments (e.g., $\mathrm{C}$ and $\mathrm{U}$ ) were assigned to each main treatment plot. Growth and yield data from each plot were analyzed with ANOVA using the GLM procedure. When differences were detected at $P \leq 0.05$, means were separated by the least significant difference technique using the Mixed procedure (SAS version 9.1).

\section{Results and discussion}

In 'Siskiyou' trailing blackberry, winter injury was the least in plants that had lateral canes positioned close to the ground and covered with a RC (Table 1, Fig. 2). In spring, the peridermal tissue was green at the tips of $\approx 67 \%$ of lateral canes on plants with 


$\stackrel{\mathrm{V}}{\mathrm{H}} \mathrm{H} \stackrel{\mathrm{V}}{\mathrm{H}}-\mathrm{H}$

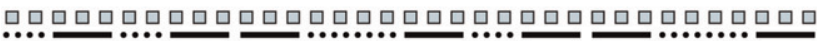

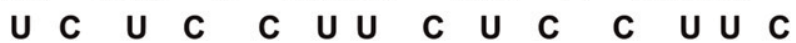

Fig. 1. Schematic drawing of the 'Siskiyou' blackberry plants used in the study and the experimental setup. In a row established originally with 35 nursery matured transplants, indicated by closed boxes $(\square)$, seven sections ( 1 to 7 from left to right) of the rotating cross-arm trellis system that could be manipulated independently were installed. $\mathrm{V}=$ lateral canes maintained upright, $\mathrm{H}=$ lateral canes laid close to the ground, $\mathrm{U}=$ plants were not covered in winter, and $\mathrm{C}=$ plants were covered with a 1.5 $\mathrm{oz} / \operatorname{yard}^{2}\left(50.86 \mathrm{~g} \cdot \mathrm{m}^{-2}\right.$ ) rowcover (Grow-Guard-51; Atmore Industries, Atmore, AL).

Table 1. The effect of vertical or horizontal cane orientation and winter protection [e.g., covered or not covered with a $1.5 \mathrm{oz} / \mathrm{yard}^{2}\left(50.86 \mathrm{~g} \cdot \mathrm{m}^{-2}\right)$ rowcover (Grow-Guard-51; Atmore Industries, Atmore, AL)] on cane injury and flower shoots emergence on 'Siskiyou' blackberry at Kearneysville, WV, in 2009.

\begin{tabular}{llcccc}
\hline $\begin{array}{l}\text { Lateral cane } \\
\text { orientation }\end{array}$ & $\begin{array}{c}\text { Winter } \\
\text { protection }\end{array}$ & $\begin{array}{c}\text { Lateral } \\
\text { canes } \\
\text { (no./plant) }\end{array}$ & $\begin{array}{c}\text { Viable lateral } \\
\text { canes } \\
\text { (no./plant })^{\mathrm{z}}\end{array}$ & $\begin{array}{c}\text { Flowering } \\
\text { shoots } \\
(\text { no./plant })\end{array}$ & $\begin{array}{c}\text { Yield } \\
(\mathbf{k g} / \text { plant })^{\mathrm{y}}\end{array}$ \\
\hline Vertical & Not covered & $31 \mathrm{a}^{\mathrm{x}}$ & $3 \mathrm{a}$ & $19 \mathrm{a}$ & $0.6 \mathrm{a}$ \\
Vertical & Covered & $37 \mathrm{a}$ & $6 \mathrm{a}$ & $49 \mathrm{a}$ & $2.0 \mathrm{a}$ \\
Horizontal & Not covered & $39 \mathrm{a}$ & $7 \mathrm{a}$ & $72 \mathrm{a}$ & $1.7 \mathrm{a}$ \\
Horizontal & Covered & $37 \mathrm{a}$ & $25 \mathrm{~b}$ & $280 \mathrm{~b}$ & $6.0 \mathrm{~b}$ \\
\hline
\end{tabular}

${ }^{2}$ Presence of green peridermal tissues at the distal ends of lateral canes pruned back to 5 - $\mathrm{ft}(1.52 \mathrm{~m})$ length. y $1 \mathrm{~kg}=2.2046 \mathrm{lb}$

${ }^{x}$ Mean separation within columns by differences of least squares means of SAS (SAS Institute, Cary, NC) Proc Mixed. Means within the same column with no letter in common are significantly different at $P=0.05$.
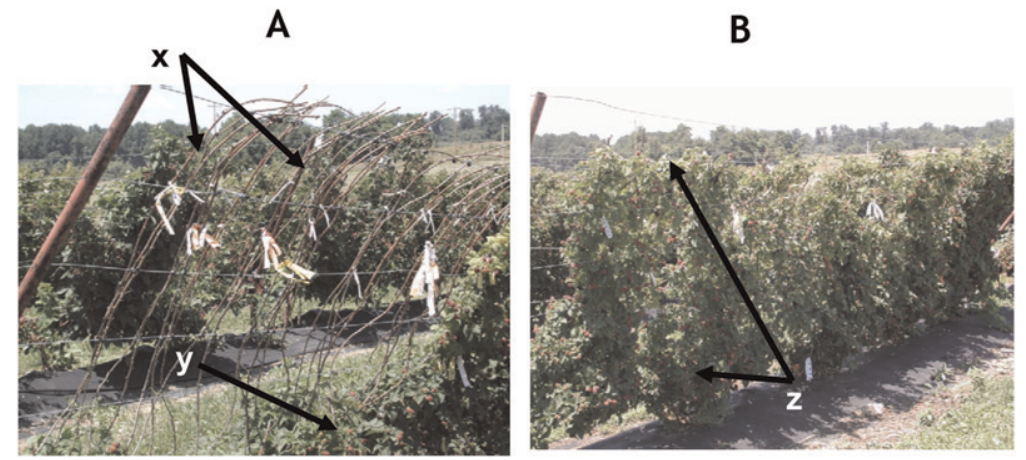

Fig. 2. 'Siskiyou' blackberry plants in spring. (A) Lateral canes of 'Siskiyou' blackberry plants that were not protected in winter with a rowcover $(\mathrm{RC})$. Note that spring growth is absent on lateral canes $(x)$ and some flowering shoots emerged from axillary buds on horizontally oriented primary canes (y). (B) A group of 'Siskiyou' plants whose lateral canes were oriented horizontally close to the ground and covered with RC [1.5 oz/yard ${ }^{2}\left(50.86 \mathrm{~g} \cdot \mathrm{m}^{-2}\right)$, Grow-Guard-51; Atmore Industries, Atmore, AL] in winter. Note that fruit clusters have developed from axillary buds on entire length of lateral canes $(\mathrm{z})$.

lateral canes oriented horizontally and under RC in winter compared with less than $19 \%$ of the lateral canes on plants that had lateral canes oriented vertically, whether covered or not. The combination of having the lateral canes oriented horizontally and RC application in 2008-2009 winter resulted in 280 flowering shoots per plant, while the plants in the other three treatments averaged only 47 flowering shoots.

Fruit were harvested from 18 June to 9 July from all plots in 2009 . 'Siskiyou' blackberry plants with lateral canes oriented horizontally and with RC produced $6.0 \mathrm{~kg}$ fruit/plant compared with $\leq 2.0 \mathrm{~kg}$ fruit/plant that were not covered with RC or for plants with lateral canes oriented vertically
(Table 1). Much of the fruit on plants that were winter-injured was produced on the fruiting laterals that developed on the primary canes (Fig. 2A). 'Siskiyou' plants that had lateral canes laid close to the ground and that were covered in winter produced flowering shoots on the entire length of lateral canes (Fig. 2B) and started to flower 1 week earlier than the unprotected plants (data not presented). Harvesting of 'Siskiyou' blackberry plants overlapped with red raspberry harvest season and occurred 3 to 4 weeks earlier than that of more winter-hardy 'Apache' and 'Triple Crown' blackberry.

In 2010, the yields of plants that had lateral canes oriented horizontally and close to the ground were as high as in previous years during which the plants were treated similarly (Table 2). However, the yields from plants in $\mathrm{HU}, \mathrm{VC}$, and VU plots were far better than the yields achieved in 2009 or in earlier years (Takeda et al., 2008). Better yields by plants in $\mathrm{HU}, \mathrm{VC}$, and $\mathrm{VU}$ plots can be attributed to more moderate temperatures during 2009-2010 winter. Also, the periods of daily minimum temperatures below $-10{ }^{\circ} \mathrm{C}$ (Fig. 3) coincided with as much as $\approx 50 \mathrm{~cm}$ of snow on the ground, which remained on top of the RC and lateral canes close to the ground (Fig. 4). With the snow on the ground, the temperatures below the $\mathrm{RC}$ remained near $0{ }^{\circ} \mathrm{C}$, while temperatures were as much 8 to $10^{\circ} \mathrm{C}$ less in the other three treatments. Wildung and Sargent (1989) observed that survival and productivity of blueberry plants in Minnesota was positively related with snow depths in winter. In this study, 'Siskiyou' blackberry plants with lateral canes laid close to the ground and protected in winter had about four times more live lateral cane length than the plants with canes vertically oriented and not protected, but their yield was only two times higher. Additional studies are needed to determine the amount of fruit harvested from fruiting shoots produced on primary and lateral canes.

Based on several parameters associated with yield that were measured in this experiment, the treatment with low lateral cane position in winter and RC application was clearly superior. The findings of this study indicate that cultivars that lack sufficient winterhardiness for production in USDA 
Table 2. The effect of vertical or horizontal cane orientation and winter protection [covered or not covered with a $1.5 \mathrm{oz} / \mathrm{yard}^{2}\left(50.86 \mathrm{~g} \cdot \mathrm{m}^{-2}\right)$ rowcover (Grow-Guard-51; Atmore Industries, Atmore, AL)] from Dec. 2009 to Mar. 2010 on cane injury and flower shoots emergence on 'Siskiyou' blackberry at Kearneysville, WV, in 2010.

\begin{tabular}{llccc}
\hline $\begin{array}{l}\text { Lateral cane } \\
\text { orientation }\end{array}$ & $\begin{array}{c}\text { Winter } \\
\text { protection }\end{array}$ & $\begin{array}{c}\text { Live lateral } \\
\text { cane length } \\
(\mathrm{cm} / \text { plant })^{\mathrm{z}}\end{array}$ & $\begin{array}{c}\text { Flowering } \\
\text { shoots } \\
(\text { no. } / \text { plant })\end{array}$ & $\begin{array}{c}\text { Yield } \\
(\mathbf{k g} / \text { plant })^{\mathrm{y}}\end{array}$ \\
\hline Vertical & Not covered & $556 \mathrm{c}^{\mathrm{x}}$ & $118 \mathrm{c}$ & $3.2 \mathrm{~b}$ \\
Vertical & Covered & $918 \mathrm{bc}$ & $157 \mathrm{c}$ & $4.4 \mathrm{~b}$ \\
Horizontal & Not covered & $1317 \mathrm{~b}$ & $241 \mathrm{~b}$ & $5.7 \mathrm{a}$ \\
Horizontal & Covered & $2287 \mathrm{a}$ & $348 \mathrm{a}$ & $6.3 \mathrm{a}$ \\
\hline
\end{tabular}

${ }^{2}$ Distal sections of lateral canes that were shriveled were pruned back to green peridermal tissue in Spring 2010 and the remaining lateral cane was measured to the primary cane; $1 \mathrm{~cm}=0.3937$ inch.

${ }^{\mathrm{y}} \mathrm{l} \mathrm{kg}=2.2046 \mathrm{lb}$.

'Mean separation within columns by differences of least squares means of SAS (SAS Institute, Cary, NC) Proc

Mixed. Means within the same column followed by a same letter not significantly different at $P=0.05$

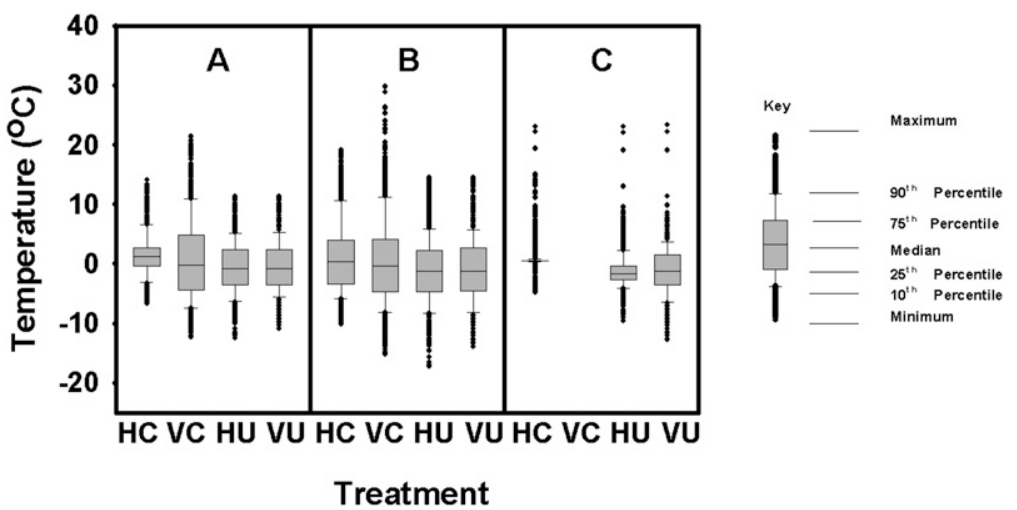

Fig. 3. The seasonality and extent of air temperature variations around lateral canes of blackberry plants inside and outside a rowcover (RC) $\left[1.5 \mathrm{oz} / \mathrm{yard}^{2}(50.86\right.$ g. $\mathrm{m}^{-2}$ ) Grow-Guard-51; Atmore Industries, Atmore, AL]. From left to right, temperature data are shown for (A) Dec. 2009, (B) Jan. 2010, and (C) Feb. 2010. The key to box-and-whisker plots are shown on the right. Treatments from left to right are horizontal cane orientation with $\mathrm{RC}(\mathrm{HC})$, vertical cane orientation with RC (VC), horizontal cane orientation with no RC (HU), and vertical cane orientation with no RC (VU). Dataloggers in VC plots malfunctioned in Feb. 2010; $\left(1.8 \times{ }^{\circ} \mathrm{C}\right)+32={ }^{\circ} \mathrm{F}$.

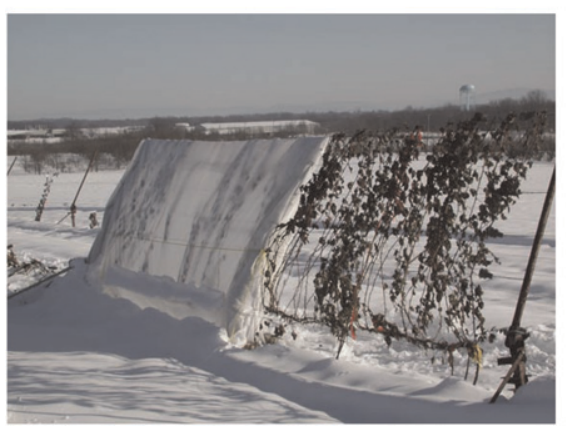

B

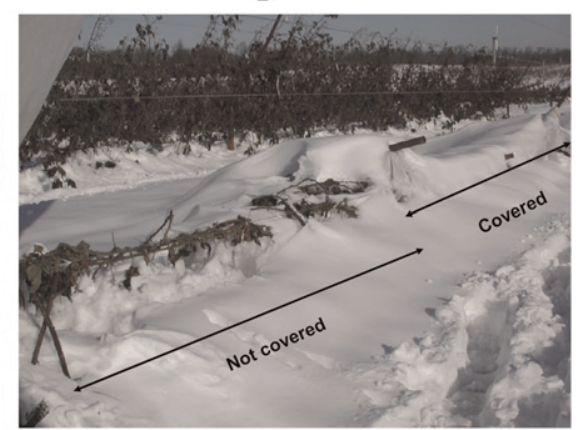

Fig. 4. Effect of cane orientation and a rowcover $(\mathrm{RC})\left[1.5 \mathrm{oz} / \mathrm{yard}^{2}\left(50.86 \mathrm{~g} \cdot \mathrm{m}^{-2}\right)\right.$, Grow-Guard-51; Atmore Industries, Atmore, AL] application on snow accumulation on top of blackberry plants in Winter 2009-2010. (A) Snow accumulation was little around plants in which the lateral canes were retained in vertical orientation during winter. (B) Plots with the lateral canes oriented horizontally. Note that there is more snow drift covering plants. Snow accumulated on a lattice created by lateral canes tied to wires on the rotating cross-arm trellis. More snow drift is visible in the background where the plants were covered than in the foreground where the plants were not covered.
Plant Hardiness Zone 6 can be satisfactorily grown in the mid-Atlantic coast region of United States and produce fruit if the adverse effects of low winter temperatures are mitigated and concur with those reported during 2004-2007 seasons (Takeda et al., 2008). The RCA trellis allowed the placement of canes close to the ground in winter. The RC was easily applied to plants with canes oriented horizontally and close to the ground. From Dec. 2008 to Feb. 2009, the temperature reached $\approx-20{ }^{\circ} \mathrm{C}$ in the open on several nights, but the temperature remained above $-17{ }^{\circ} \mathrm{C}$ under the cover on the horizontally oriented lateral canes throughout the winter (data not presented). Under these temperature regimes, covering the plants that are low to the ground with a medium-weight floating RC was sufficient to prevent extensive cane injury. Maximum daytime temperatures under the RC on the horizontally oriented lateral canes were higher than in the other three treatments and reached $>15{ }^{\circ} \mathrm{C}$ on most days between mid December and late February. Exposure of blackberry plants under RC for 2 to $3 \mathrm{~h}$ of high daytime temperatures in excess of $15{ }^{\circ} \mathrm{C}$ had little effect on their winter injury. The extent of cane injury appears more closely associated with the duration and frequency of exposure to low temperatures $\left(<-17^{\circ} \mathrm{C}\right)$. In all four treatments, 12 and $18 \mathrm{~h}$ of temperatures between -15 and $-17{ }^{\circ} \mathrm{C}$ were recorded. In plants with lateral canes oriented horizontally and covered with a RC, some winter injury did occur but the temperature did not drop below $-17^{\circ} \mathrm{C}$. In the other three treatments (e.g., not covered with a $\mathrm{RC}$ or lateral canes oriented vertically), the temperatures dropped below $-17{ }^{\circ} \mathrm{C}$ on several nights for a total of 3 to $11 \mathrm{~h}$ in late Jan. 2009 (Fig. 4) and cane injury was severe. These findings are in agreement with the results of the artificial freezing tests, which showed the midwinter $\mathrm{LT}_{50}$ (lethal temperature at which $50 \%$ of buds are killed) values for 'Siskiyou' blackberry were $\approx-17{ }^{\circ} \mathrm{C}$ (Takeda et al., 2008).

Soil temperatures were not recorded in this study, but Takeda et al. (2008) reported that soil temperatures under $\mathrm{RC}$ remained above $0{ }^{\circ} \mathrm{C}$ during the winter, but in the open, soil temperatures generally dropped below 
$0{ }^{\circ} \mathrm{C}$ as mean air temperatures fell below $-5{ }^{\circ} \mathrm{C}$ without snow cover. The results suggested that the canes must be positioned close to the ground to gain benefits from RC application, possibly because of radiant energy captured from soil. In using the RCA trellis for winter protection, the pivot point of the rotatable cross-arm should be no higher than 20 to 24 inches above the ground to ensure canes are close to the ground when the crossarms are rotated for winter.

The modifications in the production system described here have resulted in 'Siskiyou' blackberry producing $6 \mathrm{~kg}$ fruit/plant in 2009 with only three floricanes on each plant trained to the RCA trellis. In contrast, growing 'Siskiyou' without a RC or not positioning the canes close to the ground yielded $\leq 2 \mathrm{~kg}$ fruit/plant. By using the winter protection technique described in this study, more consistent production of erect and semierect blackberries has been possible in some parts of the midwestern and northeastern United States where a reliable outdoor blackberry production has not been possible (S. Bardenhagen, personal communication). The capital investment for the RCA trellis is not as high as for high tunnels, but more expensive than for the conventional "T" trellis system (R. Barnes, personal communication). Previous studies have shown that increased cost of labor for primocane training can be partially off-set with little or no labor cost for winter pruning, increased crop productivity, and lower harvest cost (Harper et al., 1999; Takeda et al., 2003). When canes of semierect cultivars were trained to the RCA trellis, the only pruning required in winter was the cutting back the lateral canes that had grown beyond the topmost wire on the crossarm (Takeda et al., 2008). In this study, using the RCA trellis and cane training system, the plant canopy of 'Siskiyou' blackberry was manipulated to position $>95 \%$ fruit to one side of the plant row as we have described for a semierect cultivar (Takeda et al., 2003). By training canes of semierect 'Chester Thornless' to the RCA trellis, the hand harvest efficiency was improved by $30 \%$ compared with those trained to a $\mathrm{T}$ trellis (Harper et al., 1999). The RCA trellis design and cane training technique helps with the re-positioning of the canes without sacrificing the production capacity of the plant and causing cane breakage during rotation of crossarms and positioning of nearly all the fruit on one side of the row. The bending of the primocanes at $\approx 20$ inch height allowed the lateral canes that developed along the horizontal portion to be easily rotated by more than $90^{\circ}$. In both 2008-2009 and 2009-2010 seasons, only 3\% (data not presented) of main and lateral canes of 'Siskiyou' blackberry were broken while rotating the cross-arms. Similarly, little or no cane breakage occurred during primocane training or cross-arm rotations in early winter and spring of erect (e.g., 'Apache') or semierect (e.g., 'Chester Thornless' and 'Triple Crown') blackberry (Takeda et al., 2003).

\section{Conclusion}

Cane injury and loss of flowering shoots in 'Siskiyou' were significantly reduced by applying a RC (e.g., 1.5 $\mathrm{oz} /$ yard $^{2}$, Grow-Guard-51) to plants with all floricanes positioned close to the ground compared with 'Siskiyou' plants with lateral canes remaining upright and uncovered in winter. This winter protection technique resulted in a western trailing blackberry producing $\approx 6 \mathrm{~kg}$ fruit/plant in the midAtlantic coast region of United States in both 2009 and 2010. Traditionally, the fruit of western trailing cultivars have been more delicate than those of the eastern erect and semierect cultivars. Although newer trailing cultivars are better adapted to shipping in the wholesale fresh market, the fruit of firmest trailing cultivars are still not as firm as the fruit from the firmest erect and semierect cultivars (C. Finn, personal communication). If winter injury could be prevented, then the production of 'Siskiyou' blackberry and other trailing blackberries in the eastern United States with shorter distances to the market would be a solution to transporting the fruit for long distances from the current production areas in California and Oregon. Also, 'Siskiyou' blackberry ripens significantly earlier compared with the erect cultivars (e.g., Apache and Triple Crown) and has potential to expand the blackberry season in the mid-Atlantic coast region of the United States by 3 or 4 weeks than is possible with currently recommended cultivars (Demchak, 2006).
Erect thornless blackberry is sufficiently winter hardy that little or no winter injury occurs in the mid-Atlantic coast region of the United States. Earlier studies showed that training canes of 'Apache' and 'Triple Crown' blackberry on RCA and applying a RC (e.g., $1.5 \mathrm{oz} / \mathrm{yard}^{2}$, Grow-Guard-51) did not reduce winter injury or improve productivity in USDA Plant Hardiness Zone 6 (Takeda et al., 2008 ). The winter protection technique described in this study continues to be refined, and the results are being verified by ongoing research on erect thornless blackberry in more colder sites (USDA Plant Hardiness Zone 5 ) such as Ithaca, NY (M. Pritts, personal communication), Circleville, $\mathrm{OH}$ (B. Rhoads, personal communication), Traverse City, MI (S. Bardenhagen, personal communication), and Ft. Wayne, IN (R. Barnes, personal communication), where blackberry production has been limited by low winter temperatures $\left(<-23{ }^{\circ} \mathrm{C}\right)$.

\section{Literature cited}

Cathey, H.M. 1990. USDA plant hardiness zone map. U.S. Dept. Agr. Misc. Publ. No. 1475 .

Cortell, J.M. and B.C. Strik. 1997. Effect of floricane number in 'Marion' trailing blackberry. I. Primocane growth and cold hardiness. J. Amer. Soc. Hort. Sci. 122:604-610.

Crandall, P.C. 1995. Bramble production: The production and marketing of raspberries and blackberries. Food Products Press, Binghamton, NY.

Demchak, K. 2006. The mid-Atlantic berry guide for commercial growers. Pennsylvania State Univ., College Agr. Sci., Coop. Ext. Publ. AGRS-97.

Demchak, K. 2009. Small fruit production in high tunnels. HortTechnology 19: 44-49.

Finn, C.E., F.J. Lawrence, B.C. Strik, B. Yorgey, and J. DeFrancesco. 1999. 'Siskiyou' trailing blackberry. HortScience 34: 1288-1290.

Harper, J.K., F. Takeda, and D.L. Peterson. 1999. Economic evaluation of improved mechanical harvesting systems for eastern thornless blackberries. Appl. Eng. Agr. 15: 597-603.

Lamont, Jr., W.J., 2005. Plastics: Modifying the microclimate for the production of vegetable crops. HortTechnology 15: $477-481$.

Pritts, M.P., R.W. Langhans, T.H. Whitlow, M.J. Kelly, and A. Roberts. 1999. Winter 
raspberry production in greenhouses. HortTechnology 9:13-15.

Stiles, H.D. 1999. Limited arm-rotation shift-trellis (LARS) and primocane management apparatus (PMA) for raspberries and blackberries (Rubus cvs. or crops). Virginia Agr. Expt. Sta. Bul. Ser. 99-1.

Takeda, F. and D.L. Peterson. 1999. Considerations for machine harvesting fresh-market eastern thornless blackberries: Trellis design, cane training systems, and mechanical harvester developments. HortTechnology 9:6-21.

Takeda, F., A.K. Hummell, and D.L. Peterson. 2003. Primocane growth in
'Chester Thornless' blackberry trained to the rotatable cross-arm trellis. HortScience 38:373-376.

Takeda, F., K. Demchak, M.R. Warmund, D.T. Handley, R. Grube, and C. Feldhake. 2008. Row covers improve winter survival and production of western trailing 'Siskiyou' blackberry in the eastern United States. HortTechnology 18:575-582.

U.S. Department of Agriculture. 2004. 2002 Census of agriculture: State data, Vol. 1. Table 33. Berries harvested for sale: 2002 and 1997, p. 496-499. 22 Dec. 2007. <http://www.usda.gov/census/ census02/volume1/us/st99_2_033.pdf>.
Trellis Growing System. 2010. Overview of the RCA (rotating cross-arm) trellis system. 19 Nov. 2010. <http://www. trellisgrowingsystems.com/resources/ RCA_Overview.pdf>.

Wells, O.S. and J.B. Loy. 1985. Intensive vegetable production with row covers. HortScience 20:822-826.

Wildung, D.K. and K. Sargent. 1989. The effect of snow depth on winter survival and productivity of Minnesota blueberries. Acta Hort. 241:232-237. 